\title{
Analisis Kesulitan Guru Matematika Kelas VII Dalam Menerapkan Pembelajaran Daring Selama Pandemi Covid-19 Di SMP Nusantara Indah
}

\author{
Anita Sri Rejeki Hutagaol ${ }^{1, \text { a) }}$, Jesika Nasari ${ }^{2, \text { b) }}$ \\ ${ }^{12}$ STKIP Persada Katulistiwa, Sintang- Kalimantan Barat \\ Email penulis: ${ }^{\text {a) }}$ boruutagaolbest@gmail.com, ${ }^{\text {b) }}$ jesikanasari@gmail.com
}

\begin{abstract}
The purpose of the study was to find out the difficulties of grade VII mathematics teachers in implementing online learning during the covid-19 pandemic at SMP Nusantara Indah. This research is a qualitative research. The subject of the research was the seventh grade mathematics teacher at SMP Nusantara Indah. Data collection tools used are interview guidelines and documents. The results of this study show that the implementation of online learning during the COVID-19 pandemic has various problems experienced by mathematics teachers, students, and parents. The problems of the mathematics teacher in the form ofdeliver learning materials online,some students are not active in participating in learning, internet quota is expensive,students lie to parents, it is difficult to get internet network. These various problems can be overcome by making learning videos,Called to school if students have problems or difficulties in participating in online learning.
\end{abstract}

Keywords: math teacher difficulties, daring learning, COVID-19 pandemic

\begin{abstract}
Abstrak
Tujuan penelitian untuk mengetahui kesulitan guru matematika kelas VII dalam menerapkan pembelajaran daring selama pandemi covid-19 di SMP Nusantara Indah. Penelitian ini merupakan penelitian kualitatif. Subjek penelitian guru matematika kelas VII SMP Nusantara Indah. Alat pengumpulan data yang digunakan adalah pedoman wawancara dan dokumen. Hasil penelitian ini menunjukkan pelaksanaan pembelajaran daring di masa pandemi covid-19 memiliki beragam problematika yang dialami oleh guru matematika, siswa, dan orangtua. Permasalahan dari guru matematika berupamenyampaikan materi pelajaran secara daring,beberapa siswa tidak aktif dalam mengikuti pembelajaran, kouta internet mahal,siswa berbohong kepada orang tua, susah mendapatkan jaringan internet. Beragam permasalahan tersebut dapat diatasi dengan membuat video pembelajaran,dipanggil kesekolah jika siswa mempunyai masalah atau kesulitan dalam mengikuti pembelajaran daring.
\end{abstract}

Kata kunci: kesulitan guru matematika, pembelajaran daring, pandemik COVID-19

Copyright (c) 2021 Hutagaol, Nasari

$\triangle$ Corresponding author:

Email Address: boruutagaolbest@gmail.com

Received 28 Juli 2021, Accepted 3 Agustus 2021, Published 20 Agustus 2021

https://doi.org/10.21009/jrpmj.v3i2.22263

\section{PENDAHULUAN}

Saat ini dunia dihadapkan dengan wabah penyakit yang disebabkan oleh virus yang bernama Coronavirus Diseases atau dikenal dengan istilah Covid-19. Munculnya Coronavirus Disease atau Covid-19 pada tanggal 31 Desember 2019 yaitu dikota Wuhan, China (Lee, 2020). Karakteristik virus ini adalah kecepatan penyebaran yang tinggi. Coronavirus Diseases atau Covid-19 juga telah mewabah di Indonesia sejak awal Maret 2020 hingga saat ini. Banyak yang mengalami kesulitan dimasa pandemi Covid-19, Salah satunya adalah lembaga pendidikan. Di sektor pendidikan, pemerintah melalui Kementerian Pendidikan dan Kebudayaan (Kemdikbud) telah menjalankan kebijakan learning from home atau Belajar Dari Rumah (BDR) terutama untuk satuan pendidikan yang berada diwilayah zona 
kuning, orange dan merah untuk satuan pendidikan yang berada dizona hijau, dapat melaksanakan pembelajaran tatap muka atau offline dengan tetap memperhatikan protokol kesehatan 3M (Mencuci Tangan, Menggunakan Masker, Menjaga Jarak).

Menurut (Thome di dalam Kuntarto, 2017:101) "Pembelajaran daring adalah suatu sistem pembelajaran yang manfaatkan sebuah teknologi multimedia seperti; kelas virtual, video, animasi online, email, pesan suara, telephone konferensi, dan video streaming online". Sementara itu, Bilfaqih \& Qomarudin(2015:1) mengatakan“Pembelajaran Daringmerupakan program penyelenggaraan kelas pembelajaran di dalam jaringan untuk menjangkau kelompok objek yang masif dan luas. Melalui jaringan, pembelajaran dapat diadakan secara masif dengan siswa yang tidak terbatas. Pembelajaran daring dapat diikuti secara gratis maupun berbayar".Berdasarkan beberapa definisi tersebut, dapat dikatakan bahwa pembelajaran dalam jaringan (daring) merupakan pembelajaran tanpa tatap muka secara langsung antara guru dan siswa tetapi dilakukan melalui online dan dilakukan melalui jaringan internet.

Menurut hasil penelitian D. B. Sae, H. Sihotang (2020), dengan judul "Analisis Hambatan Guru Mipa Dalam Pembelajaran Daring Di Smas Kr. Rantepao Di Masa Pandemi Covid 19" dapat diketahui bahwa $54.80 \%$ guru selalu mengalami hambatan mengenai media pembelajaran yang digunakan selama melaksanakan pembelajaran daring dikarenakan ada beberapa guru yang merupakan pengguna pemula dalam beberapa media pembelajaran berbasis teknologi komputer dan internet (Aziz et. al, 2020, Hastuti et al, 2021). Dari penelitian diatas, terdapat kesulitan guru dalam pembelajaran daring bisa menyebabkan pembelajaran menjadi kurang efektif. Walaupun demikian pembelajaran daring harus di jalankan disituasi pandemi ini.

Berdasarkan hasil observasi dengan guru matematika SMP Nusantara Indah terdapat kesulitan atau hambatan pada guru matematika dalam melaksanakan pembelajaran daring, yaitu guru matematika susah memberikan penjelasan materi secara daring dengan menggunakan aplikasi Zoom, beberapa siswa tidak aktif dalam mengikuti pembelajaran, siswa tidak mempunyai kouta internet untuk mengikuti kegiatan pembelajaran sehingga pembelajaran menjadi tidak efektif dan efisien, siswa banyak berbohong ketika membeli kouta untuk melaksanakan pembelajaran atau mengerjakan tugas dari guru kepada orang tua padahal kouta tersebut digunakan untuk siswa bermain game bahkan siswa menggunakan kouta tersebut untuk bermain game ber hari-hari sedangkan orang tua tidak tahu jika siswa menggunakan kouta internet untuk bermain game ketika berada dijaringan internet atau wifi sehingga siswa tidak mengerjakan tugas yang diberikan guru, dan siswa susah mendapatkan jaringan internet bagi yang berada dikampung Sehingga siswa harus menaiki bukit untuk mendapatkan jaringan internet.

Berdasarkan latar belakang, maka dirumuskan pertanyaan penelitian yaitu (1) Kesulitan apa saja yang dialami oleh guru matematika selama proses pembelajaran secara daring?; (2) Apa saja faktor yang mempengaruhi kesulitan proses pembelajaran matematika secara daring? (3) Bagaimana cara atau 
alternative dalam mengatasi kesulitan yang dialami pada proses pembelajaran matematika secara daring?.

Adapun tujuan penelitian ini adalah (1) Untuk mengetahui Kesulitan apa saja yang dialami oleh guru matematika selama proses pembelajaran secara daring; (2) Untuk mengetahui faktor yang mempengaruhi kesulitan proses pembelajaran matematika secara daring; (3) Untuk mengetahui cara atau alternative dalam mengatasi kesulitan yang dialami pada proses pembelajaran matematika secara daring.

\section{METODE}

Penelitian ini menggunakan metode penelitian kualitatif deskriptif, artinya penelitian yang digunakan untuk mengumpulkan data atau informasi sesuai dengan apa adanya pada saat penelitian dilaksanakan serta berupaya mendeskripsikan objek/subjek yang diteliti, dengan tujuan mendeskripsikan secara tersusun, fakta dan karakteristik objek yang diteliti secara tepat.

Menurut Nawawi (2015:67) "metode deskriptif dapat diartikan sebagai prosedur pemecahan masalah yang diselidiki dengan menggambarkan/melukiskan keadaan subjek/objek penelitian pada saat sekarang berdasarkan fakta-fakta yang tampak atau sebagaimana adanya".

\section{HASIL DAN PEMBAHASAN}

\section{a. Kesulitan Guru Matematika Kelas VII Selama Pembelajaran Daring}

Kesulitan berasal dari kata sulit yang berarti keadaan yang sulit, sesuatu yang sulit, kesukaran,kesusahan. Berdasarkan pengertian tersebut dapat dipahami bahwa kesulitan adalah suatu kendala atau hambatan yang dialami oleh seseorang dalam melakukan sesuatu untuk mencapai suatu tujuan dan memerlukan usaha yang keras untuk mengatasi kesulitan tersebut. Sementara guru adalah pribadi yang selalu digugu dan ditiru. Guru adalah profesi yang memerlukan keahlian khusus sebagai guru dan tidak dapat dilkukan oleh sembarang orang diluar pendidikan. Kata guru memiliki banyak sinonim kata seperti pendidik, pelatih, pengajar, trainer, tutor, dan lain sebagainya. Dimana tugas mereka adalah sama-sama mendidik dan mengajar peserta didiknya baik itu dalam pendidikan formal ataupun informal.

Nursalam (2016:6), mengatakan matematika merupakan mata pelajaran yang penting untuk diajarkan di SD/MI karena matematika sangat berguna dalam kehidupan sehari-hari siswa dan diperlukan sebagai dasar untuk mempelajari matematika lanjut dan mata pelajaran lain. Sedangkan Menurut Pascalian Hadi Pradana (2016:2), matematika merupakan salah satu mata pelajaran yang masih dianggap sulit dipahami oleh siswa.

Berdasarkan pendapat ahli diatas Matematika merupakan salah satu mata pelajaran yang diajarkan di setiap jenjang sekolah dari sekolah dasar hingga perguruan tinggi dan matematika itu sangat lah berguna dalam kehidupan sehari-hari. Sehinggga dapat disimpulkan pengertian kesulitan guru 
matematika yaitu kendala-kendala atau hambatan yang dihadapi oleh seorang guru matematika dalam melaksanakan proses pembelajaran.

\section{Menyampaikan Materi Pelajaran}

Materi pembelajaran pada hakekatnya merupakan pengetahuan, nilai-nilai dan keterampilan sebagai isi dari suatu mata pelajaran yang diarahkan untuk mencapai tujuan pembelajaran. Sehingga dapat dikatakan bahwa materi pelajaran adalah berbagai pengalaman yang akan diberikan kepada siswa selama mengikuti proses pendidikan atau proses pembelajaran. Siswa melakukan berbagai kegiatan dalam rangka memperoleh pengalaman belajar tersebut, baik itu berupa keterampilan kognitif, psikomotorik maupun afektif. Pengalaman-pengalaman ini dirancang dan diorganisir sedemikian rupa sehingga apa yang diperoleh siswa sesuai dengan tujuan.

\section{Beberapa Siswa Tidak Aktif Dalam Mengikuti Pembelajaran}

Siswa kurang aktif dalam mengikuti pembelajaran dikarena kan jaringan internet sehingga proses pembelajaran tidak efektif seperti biasanya.

\section{Kuota internet}

Kouta internet merupakan batasan pemakaianinternet pada waktu tertentu. Kouta internet bisa digunakan dimana saja yang memiliki jaringan. Kouta internet akan terputus atau semakin melambat jika sudah melebih waktu tertentu.

\section{Siswa Berbohong Kepada Orang Tua}

Berbohong merupakan memberi informasi tentang sesuatu kepada orang lain tetapi berbeda dengan kenyataannya, baik mengetahuinya, disengaja atau tidak. Berbohong merupakan sikap yang tidak baik dilakukan baik anak maupun orang tua.

\section{Susah Mendapatkan Jaringan Internet}

Pengertian jaringan internet secara umum bisa didefinisikan jaringan komputer tiada batas yang menjadi penghubung pengguna komputer dengan pengguna komputer lainnya serta dapat berhubungan dengan komputer di sebuah wilayah ke wilayah di penjuru dunia. Istilah ini lebih dikenal dengan "online" di internet. Internet merupakan sistem global jaringan komputer yang berhubungan menggunakan standar Internet Protocol Suite (TCP / IP) untuk melayani miliaran pengguna di seluruh dunia.

\section{b. $\quad$ Faktor Yang Mempengaruhi Kesulitan Guru Matematika Kelas VII}

Berdasarkan penelitian ini peneliti mendeskripsikan beberapa faktor yang mempengaruhi kesulitan guru matematika kelas VII selama menerapkan pembelajaran daring.

1. Jaringan internet

Internet merupakan singkatan dari (interconnection networking). Internet dapat diartikan sebagai jaringan komputer luas dan besar yang mendunia, yaitumenghubungkan pemakai komputer dari suatu negara ke negara lain di seluruh dunia, dimana di dalamnya terdapat berbagai sumber daya informasi dari mulai yang statis hingga yang dinamis dan interaktif. 
2. Keterbatasan Waktu dan jarak dalam mengontrol siswa

Selama pembelajaran daring dilakukan siswa belajar dari mana saja dan kapan saja. Tetapi dengan kegiatan pembelajaran daring maka sebagai orang tua sudah menjadi guru yang utama. Keterbatasan waktu dan jarak sangat mempengaruhi siswa dalam melakukan pembelajaran karena sebagai guru tidak bisa mengontrol siswa seperti yang dilakukan didalam kelas.

3. Handphone $(\mathrm{Hp})$

Handphone merupakan alat telekomunikasi elektronik dua arah yang bisa dibawa kemana-mana dan memiliki kemampuan untuk mengirimkan pesan berupa suara. Pengertian tersebut merupakan pengertian handphone secara umum. Dalam keseharian kini manusia hampir tidak bisa lepas dari handphone. Apalagi dengan semakin berkembangnya handphone sehingga handphone memiliki berbagai fungsi sekaligus. Bukan hanya sebagai alat komunikasi saja namun telah berkembang menjadi alat dengan fungsi lainnya seperti sebagai media hiburan, media bisnis, dan sebagainya. Kini kita mengenal istilah smartphone atau ponsel pintar. Sebutan untuk handphone yang bisa digunakan untuk melakukan banyak hal. Sebelum handphone memiliki fungsi seperti sekarang ini, handphone telah mengalami perjalanan yang panjang sejak awal kemunculannya.

4. Kouta Internet Mahal

Kuota internet merupakan batasan pemakaian

internet pada waktu tertentu. Kouta internet bisa digunakan dimana saja yang memiliki jaringan. Kouta internet akan terputus atau semakin melambat jika sudah melebih waktu tertentu.

\section{c. Upaya Yang Dilakukan Untuk Mengatasi Kesulitan Guru Matematika Kelas VII \\ 1. Membuat Video Pembelajaran}

Video pembelajaran adalah suatu media yang dirancang secara sistematis dengan berpedoman kepada kurikulum yang berlaku dan Dalam pengembangannya mengaplikasikan prinsip-prinsip pembelajaran dalam pengembangannya mengaplikasikan prinsip prinsip pembelajaran sehingga program tersebut memungkinkan siswa mencermarti materi pelajaran secara lebih mudah dan menarik. 2. Dipanggil Kesekolah Jika Siswa Mempunyai Masalah Atau Kesulitan Dalam Mengikuti Pembelajaran Daring.

Mempunyai kesulitan dalam mengikuti pembelajaran sangat lah mempengaruhi proses pembelajaran maka dari itu guru memberikan panggilan kepada siswa untuk mendatangi sekolah bertanya tentang materi yang belum dipahami atau mempunyai kesulitan dalam memahami pada materi yang telah dibagikan.

Pembelajaran matematika saat pandemi ini dilaksanakan dengan sistem daring. Banyak hal yang dilakukan untuk dapat tetap melaksanakan pembelajaran matematika. Pada umumnya proses pembelajaran matematika di SMP Nusantara Indah pada saat pandemi covid-19 adalah menggunakan aplikasiwhatsapp. Guru memberikan penjelasan materi, dan tugas untuk siswa melalui whatsapp group. Guru memberikan waktu untuk siswa memahami dan bertanya tentang materi yang belum dipahami. 
Hal tersebut guru lakukan supaya siswa dapat mencapai suatu kompetensi yang diharapkan. Tidak hanya melalui whatsapp, tetapi guru membuat video pembelajaran untuk siswa agar dapat mendengar langsung penjelasan materi yang disampaikan oleh gurunya.

Saat pandemi covid-19 ini banyak dampak yang dirasakan oleh guru, siswa, dan orang tua. Dampak positif yang dirasakan adalah dengan adanya pandemi covid-19 ini, berbagai elemen dibuat untuk belajar mengenal teknologi. Jika dulu belajar hanya melalui tatap muka langsung, sekarang berbagai elemen sudah mengenal whatsapp, google classroom, zoom, dan sebagainya. Mereka mulai membudayakan untuk dapat belajar secara daring. Dampak positif lainnya adalah kini guru dan siswa dapat melakukan proses pembelajaran dimana saja dan kapan saja, tidak terpaku oleh suatu ruang untuk melakukan proses belajar mengajar.

Dampak negatif juga dirasakan oleh berbagai pihak seperti guru, siswa, serta orang tua dari adanya pandemi covid-19 ini. Dampak negatif yang guru dan siswa rasakan sangat besar seperti tidak dapat memberi feedback secara cepat, pemahaman anak terhadap suatu materi kurang mendalam, kurangnya alat komunikasi, melonjaknya kebutuhan kuota internet, orang tua disibukkan oleh tugas atau pekerjaan, anak rasa jenuh pada anak ketika diberi penjelasan guru ketika pembelajaran melalui aplikasi online, kurangnya akses internet bagi yang berada dikampung.

Dari segala dampak tersebut guru matematika SMP Nusantara Indah hanya bisa meminimalisir hambatan atau kesulitan pembelajaran daring, seperti (a) membuat video pembelajaran; (b) dipanggil kesekolah jika siswa mempunyai masalah atau kesulitan dalam mengikuti pembelajaran daring.

\section{KESIMPULAN}

Berdasarkan hasil dan pembahasan maka diuraikan kesimpulan penelitian sebagai berikut:

1) Kesulitan guru matematika kelas VII selama proses pembelajaran dilakukan yaitu guru matematika susah memberikan penjelasan materi secara daring dengan menggunakan aplikasi Zoom, beberapa siswa tidak aktif dalam mengikuti pembelajaran, siswa tidak mempunyai kouta internet untuk mengikuti kegiatan pembelajaran, siswa banyak berbohong kepada orang tua dalam membeli kouta dan penggunaannya, dan siswa susah mendapatkan jaringan internet.

2) Faktor yang menyebabkan Kesulitan Guru matematika kelas VII dalam pembelajaran daring itu seperti susah jaringan internet, keterbatasan waktu dan jarak seorang guru dan orang tua dalam memantau atau mengontrol siswa bermain Handphone, beberapa siswa tidak memiliki handphone pribadi dan siswa tidak memiliki kouta internet atau kouta internet mahal.

3) Upaya yang dilakukan untuk mengatasi kesulitan guru matematika kelas VIIdalam pembelajaran daring seperti membuat video pembelajaran, serta video pembelajaran diupload ke Youtube agar penyimpanan di Handphone tidak terlalu berat dan memberikan panggilan 
kepada siswa yang mempunyai masalah pada handphone untuk datang kesekolah bertanya secara manual.

\section{DAFTAR PUSTAKA}

Aziz, T. A., \& Akgül, M. B. (2020). Proses Kognitif dan Metakognitif Siswa dalam Memecahkan Masalah Matematika. Jurnal Riset Pendidikan Matematika Jakarta, 2(2), 7186. https://doi.org/10.21009/jrpmj.v2i1.10446

Amalia, A., \& Fatonah , S. (2020). Penerapan Pembelajaran Daring Dragonlearn Pada Era Pandemi Covid-19 Studi Kasus Di MI Ma'had Islam Kopeng). ISEJ: Indonesian Science Education Journal, $1(3), 148-164$.

Asmuni, A. (2020). Problematika Pembelajaran Daring Di Masa Pandemi Covid-19 Dan Solusi Pemecahannya. Jurnal Paedagogy, 7(4), 281-288

Darmadi, H. (2016). Tugas, Peran, Kompetensi, Dan Tanggung Jawab Menjadi Guru Profesional. Edukasi: Jurnal Pendidikan, 13(2), 161-174.

Hastuti, E. S., Eclarin, L., \& Dalam, K. K. S. (2021). Kecemasan Siswa Sekolah Menengah Pertama Menyelesaikan Masalah SPLDV Pada Kelas Virtual Dalam. International Journal of Progressive Mathematics Education, 1(1), 64-84. https://doi.org/10.22236/ijopme.v1i1.6914

Herliandry, Luh Devi, Dkk. (2020). Pembelajaran Pada Masa Pandemi Covid-19. Jurnal Teknologi Pendidikan. 22(1)

Hidajat, D., Pratiwi, D. A., \& Afghohani, A. (2019, October). Analisis kesulitan dalam penyelesaian permasalahan ruang dimensi dua. In Prosiding Seminar Nasional Pendidikan Matematika II (SNPMAT II): Pembelajaran Matematika dalam Era Revolusi Industri 4.0 (p. 82). Universitas Halu Oleo Press

Hidayawati, M. S. (2020). Analisis Pembelajaran Daring Melalui Whatsapp Group (Wag) Pada Mata Pelajaran Ekonomi Bisnis Di Smk Negeri 1 Talaga (Doctoral dissertation, FKIP UNPAS).

Kencanawaty, G., Febriyanti, C., \& Irawan, A. (2020). Tantangan Dan Strategi Pembelajaran Matematika Di Masa Adaptasi Kebiasaan Baru (AKB) Dampak Dari Covid-19. Diskusi Panel Nasional Pendidikan Matematika 6(1)

Kirom, A. (2017). Peran guru dan peserta didik dalam proses pembelajaran berbasis multikultural. Al Murabbi, 3(1), 69-80

Makrufah, S. N. (2020). Analisis Kesulitan Guru Matematika Mts Pangeran Diponegoro Salaman Tahun Pelajaran 2019/2020 Dalam Menerapkan Pembelajaran Daring (Dalam Jaringan) Selama Masa Pandemi Virus Corona. Tidak diterbitkan

Riana Rusita. (2019). Analisis Minat Belajar Matematika Siswa Kelas IV Sekolah Dasar Negeri 4 Sirang Setambang Tahun Pelajaran 2018/2019. Tidak diterbitkan

Sae, D. B., \& Sihotang, H. (2020). Analisis Hambatan Guru Mipa Dalam Pembelajaran Daring Di Smas Kr. Rantepao Di Masa Pandemi Covid 19. EduMatSains: Jurnal Pendidikan, Matematika dan Sains, 1(1), 1-12.

Sanjani, M. A. (2020). Tugas Dan Peranan Guru Dalam Proses Peningkatan Belajar Mengajar. Serunai: Jurnal Ilmiah Ilmu Pendidikan, 6(1), 35-42.

Sopian, A. (2016). Tugas, Peran, dan Fungsi Guru dalam Pendidikan. Raudhah Proud To Be Professionals: Jurnal Tarbiyah Islamiyah, 1(1), 88-97

How to cite : Hutagaol, A. S. R., \& Nasari, J., 2021. Analisis Kesulitan Guru Matematika Kelas VII Dalam Menerapkan Pembelajaran Daring Selama Pandemi Covid-19 Di SMP Nusantara Indah. Jurnal Riset Pendidikan Matematika Jakarta. 3(2). 15-22. https://doi.org/10.21009/jrpmj.v3i2.22263

To link to this article: $\underline{\text { https://doi.org/10.21009/jrpmj.v3i2.22263 }}$ 